\title{
Alexandra Pita González (comp.), Redes intelectuales transnacionales en América Latina durante la entreguerra, México, Universidad de Colima y Miguel Ángel Porrúa, librero-editor, 2016, 288 pp. (Serie Las Ciencias Sociales, Tercera Década). ISBN: 978-607-524-059-6
}

Verónica Oikión Solano*

Sus autoras y autores han logrado darle unidad a este volumen al confluir —desde distintas apreciaciones - en el giro de la historia intelectual, ofreciéndonos un panorama considerablemente rico.

A quien le apasione la Historia, y aunque no sea especialista en las temáticas referidas en la obra, quedará gratamente sorprendido de la solvencia académica con la cual se han explicado los asuntos abordados en torno a las redes intelectuales en el periodo de entreguerras. Los enlisto a continuación: Daniel Iglesias: "Las Redes Político-Intelectuales y los orígenes del Plan Barranquilla, 1929-1931". "Un resplandor en el Nuevo Mundo: la Red Clarté y el pacifismo en América Latina, 1918-1938" de la autoría de Fabio Moraga Valle. Alexandra Pita aborda "La difusión de un discurso latinoamericanista y la creación de una red intelectual, 1922-1924". Por su parte, Marco Antonio Vuelvas Solórzano explica "La formación de la red en torno a la Revista Ulises 1927”. María del Carmen Grillo atiende "Una Red en el Tiempo. El caso de La Campana de Palo, 1925-1927'. Irma Guadalupe Villasana Mercado se centra en "Redes Intelectuales y circulación de bienes culturales: Ábside. Revista de Cultura Mexicana, 1937-1938”. "A través de lecturas: la conformación de una red intelectual en la sección bibliográfica de la Revista de Filosofía, 19151922" es la temática a la que se refiere Cristina Beatriz Fernández. Blanca Mar León Rosabal se enfoca en "La Revista Cubana durante el periodo de entreguerras, 1935-1938". En seguida, Pablo Manuel Requena desarrolla su

* El Colegio de Michoacán. 
estudio sobre "Los vínculos continentales de la Junta de Historia y Numismática Americana, 1924-1937”. Por último, Regina Crespo se cuestiona “¿Crónica de una ausencia anunciada? Brasileños en redes intelectuales argentinas”.

Esta obra dilucida y ahonda en un campo de conocimiento —el de la historia cultural e intelectual y con un enfoque transnacional bien marcadopara ofrecernos todas sus potencialidades, entre otras, las enfocadas con una mirada prosopográfica, cuya complementariedad en el estudio de redes no resulta antagónica, según nos explica la compiladora del volumen (página 9).

En torno a la tesitura analítica de la obra coincidimos con lo planteado por la historiadora colombiana María Cristina Pérez, quien afincada en las pautas diseñadas por John H. Elliot, ha precisado que:

El establecimiento de interconexiones, redes y vínculos ha cautivado a las ciencias sociales en las últimas décadas, estimulando el desarrollo de lo que se ha denominado historias conectadas, historias trasatlánticas, historias globales, historias transnacionales o historias cruzadas [...]. La historia transnacional supuso el establecimiento de vínculos que superan los territorios delimitados políticamente y que pueden conectar de manera simultánea varias partes del mundo. ${ }^{1}$

En este tenor, la sugerente metodología aplicada en la obra da por resultado un potente caleidoscopio, hilvanando en un abigarrado espacio latinoamericano a los creadores de cultura y de ideas; una de cuyas aspiraciones fue alcanzar, con espíritu libertario, la tan ansiada modernidad en un tiempo preciso - el término de la gran guerra, los años veinte y hasta fines de los treinta-. Conocimiento, cultura y prácticas culturales, mediante la producción de revistas fundadas por empresas culturales, imprentas, librerías y editoriales y, sobre todo, su circulación transnacional, con crítica y posicionamiento ideológico de por medio y hasta con tintes políticos, se convirtieron en vertientes sociales que confluyeron en el crisol de las distintas redes que esta obra magnífica nos muestra.

A lo largo de las páginas del libro, cuya vocación es el análisis de prácticas culturales mediante la reproducción de ideas y el desarrollo de instituciones ligadas a la cultura, visualizamos a conglomerados estudiantiles. También a intelectuales, pensadores, abogados, historiadores, filósofos, diplomáticos, educadores, artistas, músicos, críticos de arte, grabadores, dibujantes, pintores, escritores, periodistas y creadores literarios, quienes recrean sus vivencias más intensas y sus mundos imaginarios aferrados a las corrientes del pensamiento de la época.

1 María Cristina Pérez, "Presentación del dossier 'Redes y conexiones en la historia'”, Historia Crítica, núm. 55, Departamento de Historia de la Universidad de los Andes, Bogotá, eneromarzo 2015, p. 14. 
De ahí que sus sociabilidades vanguardistas se expresen en las ciudades letradas como lectoras, productoras y difusoras de conocimientos y discursos, y, por supuesto con el objetivo implícito de alcanzar un estatus e influir en la dimensión pública, como bien ha explicado Ángel Rama en su obra clásica de la cultura latinoamericana, La Ciudad Letrada. ${ }^{2}$

Por ende, las páginas de este libro expresan disonancias y estridencias del fluir de tendencias teóricas, filosóficas, literarias y políticas. En esencia, lo que se busca es concretar "la revolución de los espíritus" al proclamar la elevación del pueblo. Incluso, se llega a promover la Internacional del Pensamiento como barrera de contención contra el colonialismo y el imperialismo yanqui.

El libro muestra enfáticamente cómo las ideologías, la política, el poder, y la fuerza misma del Estado - en todos sus tonos latinoamericanos autoritarios, dictatoriales y hasta seudo democráticos - horadan y atraviesan, ya sea imperceptible o de manera más visible y contundente, los nodos, el andamiaje y la urdimbre configurativa de estas redes. Pero éstas, a su vez, funcionan dialécticamente como agentes en el espacio transnacional periférico para entablar diálogos, y a la vez también para debatir el repertorio político del que se nutren los poderes fácticos y los poderes efectivos en las latitudes latinoamericanas.

Si bien estoy de acuerdo con la compiladora de la obra, en que necesariamente los estudios que integran el volumen son parciales "al estar acotados no sólo por las variables de tiempo y espacio, sino también por la perspectiva teórica y metodológica que se utilice", en este caso específico la de "las redes sociales" (página 5), habría que detallar que esa parcialidad no significa de ningún modo una postura miope o limitativa. Muy por el contrario, la lectura de este libro nos abre la vía para el conocimiento puntual de la aventura intelectual latinoamericana de entreguerras. Las autoras y autores de la obra problematizan su conceptualización y acentúan "en su análisis la vinculación y relación entre un conjunto de participantes", como bien expresa la compiladora (página 5).

La obra en su conjunto atiende el análisis metodológico de las redes como armazones y soportes productores de alegatos, invocaciones y pronunciamientos en los espacios latinoamericanos; pero también como tramas creadoras de corrientes y reflexiones dinámicas y enérgicas, contribuyendo de manera tangible e intangible a la instauración y renovación de una identidad nacional, regional y en un marco histórico de dimensión transnacional. En este tránsito no podemos olvidar y menos dejar de lado las revistas y su carga de ideas; estos artefactos y dispositivos, en su materialidad, son convertidos plenamente en las correas de transmisión del pensamiento latinoamericano, pero asumido igualmente como universal, pues se reafirma su universalidad mediante distintas

2 Ángel Rama, La Ciudad Letrada, prólogo de Hugo Achugar, Montevideo, Editorial Arca, 1998. 
estrategias en su producción, circulación, intercambio y consumo. Las tácticas de trasvase y militancia cultural se nutren también de otros bienes culturales simbólicos, como lo son las cartas, los diarios, las memorias, los manuscritos, los viajes y las estancias culturales, las conferencias, los congresos, los círculos y espacios académicos universitarios, las peñas culturales, la edición de libros, etcétera.

Las revistas culturales, que observan los distintos capítulos de esta obra colectiva, son vehículos de comunicación reproducidos en marcos nacionales e internacionales que, en última instancia, afianzan la internacionalización de sus redes productoras.

La exploración colectiva que este volumen realiza acerca de las redes sociales transnacionales confirma la importancia de atender "la gran variedad de relaciones, lazos e interacciones que vinculan a personas e instituciones más allá de las fronteras de los Estados-nación". ${ }^{3}$ Asimismo, este volumen corrobora lo ya señalado en su momento por la especialista española Marta Casáus Arzú, quien precisa que dicha trascendencia

radica en la posibilidad de calibrar e, incluso, medir el complejo sistema de vínculos y la circulación de bienes y servicios, materiales e inmateriales, que se establecen entre los diferentes miembros de las redes; pero también permite conocer la red de sociabilidad que se establece entre los mismos, los espacios culturales y simbólicos del grupo, así como sus mecanismos de funcionamiento y sus estrategias para lograr la hegemonía político-cultural en momentos determinados. ${ }^{4}$

En la obra encontraremos, por tanto, los flujos y los intercambios intelectuales de determinadas comunidades imaginadas, así como sus liderazgos y sus miembros más destacados, que reciben, intercambian e interconectan ideas, símbolos, doctrinas, conceptos, aforismos y juicios por dentro y en la periferia de las redes; en cuyos repertorios se apreciará hasta qué punto aquellos caudillos culturales, sus seguidores, animadores e intermediarios imprimen organicidad y solidez a su propia red; llamada egocéntrica en algunos casos, es decir, ególatra o individualista, cuando es evidente la funcionalidad carismática del personaje que hegemoniza determinada red, como es el caso, por ejemplo, de José Vasconcelos, José Ingenieros o Rómulo Betancourt.

Las redes se nos presentan como receptáculos o depósitos de un importante acervo intelectual, no estático, sino al contrario, muy vivo, en cuyo basamento

3 Florencia Peyrou y Darina Martykánová, "Presentación. Dossier La Historia Transnacional", Ayer, núm. 94, Revista de Historia Contemporánea, Asociación de Historia Contemporánea y Marcial Pons-Ediciones de Historia, Madrid, 2014 (2), p. 13

$4 \quad$ Marta Casáus Arzú, prólogo a la obra de Eduardo Devés-Valdés, Redes intelectuales en América Latina. Hacia la constitución de una comunidad intelectual, Santiago de Chile, Instituto de Estudios Avanzados de la Universidad de Santiago de Chile, 2007 (Colección Idea, segunda época), p. 22. 
y en constante ebullición radica la secular tradición latinoamericana, con sus luminosos orígenes prehispánicos e indígenas, en hibridación y permanente mestizaje. Además, los caudales intelectuales se nos muestran en persistente confrontación e interrelación comunicativa con sus pares en distintos puntos del mapa latinoamericano y sus vasos comunicantes hacia Europa.

Finalmente, extrañé a lo largo de las páginas de la obra la presencia más definida y la acción femenina de envergadura dentro de estas redes culturales. Aquí seguramente existe una asignatura pendiente para rescatar a las intelectuales, las artistas y las educadoras que también entregaron su granito de arena a las mejores causas del pensamiento latinoamericano de la época. 